\title{
A personagem de autoficção: anotações de uma hipótese para textos futuros
}

\author{
The character of autofiction: notes of a hypothesis for future texts \\ Renato Prelorentzou \\ Universidade de São Paulo - São Paulo - Brasil
}

$\diamond$

\begin{abstract}
Resumo: Este artigo tem o estranho intento de reunir algumas ideias iniciais para futuras abordagens sobre o fenômeno da autoficção. Sem desconsiderar o longo e polêmico debate em torno do termo, procura analisá-lo a partir da leitura do clássico A personagem de ficção e da ideia de insuficiência do conceito de fiction tal como proposto por Catherine Gallagher (2009). A maior tentativa é sugerir que o pacto ficcional forte e inequívoco que o romance firmou talvez seja uma exceção na história da literatura e que o pacto ambíguo que a autoficção agora propõe talvez seja uma espécie de reedição da instabilidade ontológica que foi suprimida pelo romance tradicional.
\end{abstract}

Palavras-chave: Autoficção; Romance; Personagem; Narrador

\begin{abstract}
This article has the strange attempt to gather some initial ideas for future approaches on the phenomenon of autofiction. Without disregarding the long and controversial debate around the term, it seeks to analyze it in the light of the classic A personagem de ficção and of the insufficiency of the concept of fiction as proposed by Catherine Gallagher (2009). The major attempt is to suggest that the strong and unequivocal fictional pact that the novel established may be an exception in the history of literature and that the ambiguous pact that autofiction now proposes may be a kind of update of the ontological instability which has been suppressed by the traditional novel.
\end{abstract}

Keywords: Autofiction; Nnovel; Character; Narrator

You know who I am / you've stared at the sun

Well I am the one who loves / changing from nothing to one

LEONARD COHEN

Perto do final de Em busca do tempo perdido, o narrador relembra o momento em que recebeu a notícia da morte de Robert de Saint-Loup, amigo de longa data que acabara de retornar ao front da Grande Guerra. Abalado, ele adia planos e se põe a recordar passagens da amizade, desde o dia em que haviam se conhecido num hotel à beira-mar até os relatos que agora lhe chegavam e diziam que Saint-Loup por generosidade se lançara às trincheiras inimigas.

E tê-lo visto, em suma, tão pouco, em sítios tão vários, em circunstâncias tão diversas e separadas por longos intervalos, naquele hall de Balbec, no café de Rivebelle, no alojamento dos oficiais de cavalaria e nos jantares militares em Doncières, no teatro onde esbofeteara um jornalista, em casa da princesa de
Guermantes, dava-me, de sua vida, quadros mais sugestivos, mais nítidos, da sua morte um sofrimento mais lúcido do que os em regra deixados por pessoas mais amadas, vistas, porém, tão continuamente que a imagem se lhes dilui numa espécie de vaga média de uma infinidade de figuras insensivelmente diferentes (PROUST, 2006, p. 186-187).

Centenas de páginas depois, o narrador conta que estava chegando a uma recepção no palácio dos Guermantes quando um desnível nas pedras do pátio o fez recordar do calçamento de uma igreja veneziana, e foi justamente essa recordação involuntária, essa reminiscência do corpo que então o fez refletir sobre a natureza do tempo e da memória e conceber a forma do livro que enfim viria escrever - e que por todo o século 
chegaria às mãos de todo o mundo, a obra monumental em que, centenas de páginas antes, recordando as manhãs de Albertine a despertar, o narrador diz a célebre frase da literatura de si:

Logo que recuperava a palavra, dizia: "Meu" ou "Meu querido", seguidos um ou outro do meu nome de batismo, o que, atribuindo ao narrador o mesmo nome que ao autor deste livro, daria: "Meu Marcel", "Meu querido Marcel” (PROUST, 2006, p. 87).

A escrita da indagação sobre o conhecimento que temos da vida dos outros, das pessoas mais amadas e das menos constantes. A escrita que coincide os nomes próprios do narrador e do autor. A escrita do momento mesmo em que eles descobriram como escrever o livro que temos em mãos. Hoje parece que no romance de Proust sobre o passado havia algo do futuro.

\section{A personagem de ficção}

Em "Literatura e personagem", artigo que abre o estudo clássico que publicou com Antonio Candido, Décio de Almeida Prado e Paulo Emílio Salles Gomes, Anatol Rosenfeld diz que os textos ficcionais se caracterizam por projetarem, à diferença dos outros registros, seres e mundos que não se referem a realidades autônomas, dotadas de existência extratextual. Essa característica, tais textos não conseguem escondê-la, "revelam nitidamente a intenção ficcional, mesmo quando esta intenção não é objetivada na capa do livro, através da indicação 'romance', 'novela', etc.". É sempre nítido, diz ele, o esforço do ficcionista em multiplicar e esquematizar "pormenores circunstanciais, que visam dar a aparência de real à situação imaginária". E é justamente essa aparência de realidade, esse "vigor dos detalhes", essa "veracidade de dados insignificantes", essa "coerência interna", essa verossimilhança, enfim, que, de maneira paradoxal, mesmo nos romances que mais se aproximam da história, faz com que as orações não consigam senão denunciar "de imediato, apesar do contexto histórico, a intenção ficcional" (ROSENFELD, 2002, p. 20-21). No entanto, ainda mais que as orações e os detalhes, é a personagem que revela a ficção:

Há numerosos romances que se iniciam com a descrição de um ambiente ou paisagem. Como tal poderiam possivelmente constar de uma carta, um diário, uma obra histórica. É geralmente com o surgir de um ser humano que se declara o caráter fictício (ou não-fictício) do texto, por resultar daí a totalidade de uma situação concreta em que o acréscimo de qualquer detalhe pode revelar a elaboração imaginária (ROSENFELD, 2002, p. 23).
A presença do ser humano e a concretude de sua situação abrem ao narrador a possibilidade de empregar verbos que definem estados de ânimo e processos psíquicos. E, quando se diz que esta ou aquela personagem "pensou", "duvidou", "se sentiu" ou "se lembrou", quando o narrador se julga capaz de descrever experiências e conhecimentos que, "por razões epistemológicas", não poderiam aparecer nos escritos de um historiador ou biógrafo, aí se vê, manifesta, a ficção (2002, p. 24).

Esses argumentos levam Rosenfeld a se voltar ao problema das diferenças entre pessoa e personagem, sobretudo aos diferentes modos de conhecê-las. A pessoa real, concreta, diz ele, assume um sem-fim de predicados, dos quais só podemos colher uns poucos, pois a operação cognoscitiva que faz essa colheita é necessariamente finita e nunca consegue esgotar a infinda multiplicidade da pessoa real, que é "inefável". Nossa capacidade de ver o mundo e especialmente os seres humanos é "fragmentária e limitada" (ROSENFELD, 2002, p. 32).

Mas, por estranho que pareça, essa nossa limitação se converte na maior conquista da obra ficcional: como em algum momento precisa dar fim a suas frases, terminar o livro, o autor tem de selecionar aspectos e, assim, pode realçar traços e, por isso, as personagens ganham os contornos definidos que não vemos na observação do real, o caráter definitivo que sempre faltará às pessoas reais. Porque são limitadas, diz Rosenfeld, as sentenças fazem com que as personagens tenham uma existência que a "vida empírica, no seu fluir cinzento e cotidiano", quase nunca "apresenta de modo tão nítido e coerente" (2002, p.45). A ficção é o único lugar em que os seres humanos nos aparecem coesos e cristalinos. Não deixa de ser curioso, portanto, que Rosenfeld sugira, mesmo de passagem, que a melhor ficção fuja dessa nitidez, dessas transparências, dessas coerências que são suas maiores conquistas ante o real:

Os grandes autores, levando a ficção ficticiamente às suas últimas consequências, refazem o mistério do ser humano, através da apresentação de aspectos que produzem certa opalização e iridescência, e reconstituem, em certa medida, a opacidade da pessoa real (ROSENFELD, 2002, p. 35).

Num certo jeito de ler o clássico A personagem de ficção, este é um ponto de passagem do primeiro para o segundo artigo, "A personagem do romance", no qual Antonio Candido percorre algumas das questões de Rosenfeld e chega a respostas parecidas. Depois de dizer que "o enredo existe através das personagens, as personagens vivem o enredo", Candido também se volta ao problema da "relação entre o ser vivo e o ser fictício" (2002, p. 53, 55), na qual se impõe, mais uma vez, o caráter incompleto de nosso conhecimento dos outros: 
O romance, ao abordar as personagens de modo fragmentário, nada mais faz do que retomar, no plano da técnica de caracterização, a maneira fragmentária, insatisfatória, incompleta, com que elaboramos o conhecimento dos nossos semelhantes. Todavia, há uma diferença básica entre uma posição e outra: na vida, a visão fragmentária é imanente à nossa própria experiência; é uma condição que não estabelecemos, mas a que nos submetemos. No romance, ela é criada, é estabelecida e racionalmente dirigida pelo escritor, que delimita e encerra, numa estrutura elaborada, a aventura sem fim que é, na vida, o conhecimento do outro. Daí a necessária simplificação, que pode consistir numa escolha de gestos, de frases, de objetos significativos, marcando a personagem para a identificação do leitor, sem com isso diminuir a impressão de complexidade e riqueza (CANDIDO, 2002, p. 58).

$\mathrm{Na}$ vida, interpretamos as pessoas para conferir um mínimo de unidade à sucessão dos seus modos de ser. $\mathrm{Na}$ ficção, os romancistas também interpretam personagens, mas a lógica que lhes conferem é menos inconstante. Nossa interpretação é fluida e varia no tempo, a do romancista é mais fixa e precisa. Conforme o saber especialmente a psicanálise - foi aprofundando o mistério das pessoas, diz Candido, também a ficção renunciou à "geografia precisa dos caracteres". O romancista moderno procurou justamente aumentar a complexidade dos seres fictícios, dar a eles a impressão de uma natureza também aberta, ilimitada e contraditória. Mas, ainda que "a marcha do romance moderno (do século XVIII ao começo do século XX)" tenha seguido no "rumo de uma complicação crescente da psicologia das personagens", o romancista nunca se livrou do fato de que "essa natureza é uma estrutura limitada, obtida não pela admissão caótica dum sem-número de elementos, mas pela escolha de alguns elementos, organizados segundo uma certa lógica de composição, que cria a ilusão do ilimitado" (CANDIDO, 2002, p. 58-60). Em outras palavras: por mais que quisesse escapar à limitação que era também sua "maior conquista", o romance nunca deixava de ser uma construção determinada, artificial.

Já o problema da diferença entre pessoa e personagem, Candido o aborda sob o ponto de vista de quem cria: "No processo de inventar a personagem, de que maneira o autor manipula a realidade para construir a ficção?". A resposta, diz ele, nos ajudaria a entender em que medida um ser é reproduzido ou inventado. "Os casos variam muito, e as duas alternativas nunca existem em estado de pureza" (Candido, 2002, p. 66). O que se indaga, portanto, é o grau de afastamento em relação ao real, a proporção em que no trabalho criador se combinam memória, observação e imaginação. Há personagens, diz Candido, que exprimem traços físicos ou psicológicos de um ser existente - o próprio romancista ou qualquer outra pessoa que ele capte ao observar ou se lembrar de alguém. Mas "só poderemos decidir a respeito quando houver indicação fora do próprio romance - seja por informação do autor, seja por evidência documentária. Quando elas não existem, o problema se torna de solução difícil" (CANDIDO, 2002, p. 70).

Essa dificuldade de lidar com o extraliterário talvez tenha levado Candido a pôr ênfase na ideia de coerência interna. Para ele, a verossimilhança propriamente dita, a possibilidade de comparar o mundo do romance com o mundo real, depende da "organização estética". Assim, a verdade da personagem

não depende apenas, nem sobretudo, da relação de origem com a vida, com modelos propostos pela observação, interior ou exterior, direta ou indireta, presente ou passada. Depende, antes do mais, da função que exerce na estrutura do romance, de modo a concluirmos que é mais um problema de organização interna que de equivalência à realidade exterior (CANDIDO, 2002, p. 75).

A vida da personagem decorre da economia do livro, de sua relação com os demais elementos que o constituem. "Daí a caracterização depender de uma escolha e distribuição conveniente de traços limitados e expressivos, que se entrosem na composição geral e sugiram a totalidade dum modo-de-ser, duma existência" (CANDIDO, 2002, p. 75). É a isso que Candido dá o nome de convencionalização: o trabalho de selecionar e relacionar traços significativos, dada a impossibilidade de descrever a totalidade dos seres.

A partir dessas reflexões, Candido chega a uma espécie de corolário sobre a verdade e a verossimilhança. É comum que julguemos inverossímil, diz ele, algum fato de romance que nos pareça impossível no mundo real. Mas na vida tudo é possível e no romance é que "a lógica da estrutura impõe limites mais apertados, resultando, paradoxalmente, que as personagens são menos livres, e que a narrativa é obrigada a ser mais coerente do que a vida". Assim, Candido corrige nossas noções sobre o tema: "O que julgamos inverossimil, segundo padrões da vida corrente, é, na verdade, incoerente, em face da estrutura do livro". Por mais importante que seja para o romance o desejo de representar a realidade, fundamental mesmo é o "critério estético de organização interna. Se esta funciona, aceitaremos inclusive o que é inverossímil em face das concepções correntes" (CANDIDO, 2002, p. 76-77).

Depois de meio século de $A$ personagem de fição, talvez caiba perguntar se esse critério ainda funciona. Anatol Rosenfeld e Antonio Candido partiram da análise da personagem. Logo tiveram de passar às diferenças entre seres reais e fictícios. Nisso se viram indagando 
o próprio estatuto da ficção. E, como se fundaram em um conceito de ficção que o próprio Candido chama de moderno - do século XVIII ao começo do século XX, ele diz em uma passagem -, seus juízos, límpidos e irrefutáveis, chegaram à ênfase na "coerência interna". Quando me pergunto se talvez não valha questionar se isso ainda funciona, estou perguntando, na verdade, se continua sendo esse o regime ficcional em que vivemos.

\section{O conceito de ficção - o pacto forte e inequívoco}

"Nada no romance é tão óbvio e ao mesmo tempo tão invisível quanto o fato de ser ficção". É com esta frase Catherine Gallagher (2009, p. 629) abre um ensaio no qual discute como a ascensão do novel operou transformações na ideia de fiction.

\begin{abstract}
O novel não é apenas um gênero de narrativa ficcional dentre outros, é o gênero por meio do qual a ficção torna-se explícita e manifesta e é compreendida e aceita por todos. (...) Os romancistas do século XVIII libertaram a ficção ao renunciarem às tentativas daqueles que lhes antecederam de convencer os leitores de que suas histórias eram verdadeiras ou, de algum modo, diziam respeito a pessoas reais. (...) Convenceram os seus leitores a aceitarem o estatuto imaginário das personagens, aprisionando-as, porém, nos limites do crível. Em suma, o novel ao mesmo tempo descobriu e ocultou a ficção (GALLAGHER, 2009, p. 630).
\end{abstract}

Antes do novel, diz Gallagher, sempre existiram narrativas que não queriam ser tomadas como verdade. Os contos populares, as alegorias, as fábulas e os poemas, nenhum desses gêneros pré-modernos tinha qualquer pretensão de representar o real. Eram apenas fantasia, inverossímeis demais para que alguém as confundisse com a realidade e, assim, pensasse que sobre ela proferiam sentenças verdadeiras ou falsas. Por outro lado, continua Gallagher, também existiam os romance, aquilo que tantas vezes se traduz por romanesco, a literatura de cavaleiros heroicos que quase sempre aparece como antecessor do novel.

Os romance exaltavam aristocratas ou damas da corte, elevando-os a exemplos de virtude, enquanto as chroniques scandaleuses, como eram chamadas as sátiras difamatórias, parodiavam as convenções dos romance, invertendo-lhes os juízos (GALLAGHER, 2009, p. 633).

Os personagens dessas narrativas, mesmo que fossem mágicos ou monstruosos, eram identificados como caricaturas de pessoas reais - e do escândalo e da polêmica provinha, é claro, a popularidade. Mas, acusados de difamação e fraude, os autores de romance passaram a se defender alegando ter publicado uma obra puramente imaginativa: para evitar as consequências legais por difamar ou mentir, ajudaram a formular um novo gênero e a precisar um conceito mais refinado de ficção.

Nas primeiras décadas do XVIII, raramente ocorria de narrações verossímeis serem acolhidas como histórias de indivíduos totalmente imaginários, como viria a tornar-se absolutamente normal para leitores europeus do século ulterior. Faltava ainda algo para que isso ocorresse: uma categoria conceitual de ficção, no sentido de histórias críveis que não tivessem a pretensão se serem tomadas por verdadeiras. Foi o novel que proporcionou a junção das duas coisas, fato que explica a relação paradoxal que mantém com a ficção. Esta, com efeito, torna-se perceptível apenas quando se torna crível: visto que a diferença entre ficções e mentiras tornara-se menos óbvia, e a ausência de credibilidade não era mais o único critério distintivo, fez-se necessária uma verdadeira conceituação. Isto é, a ficção elaborou um discurso próprio ao tornar-se menos vistosa: quanto menos era evidente, mais tinha necessidade de emergir como categoria conceitual (GALLAGHER, 2009, p. 633).

Nasce o novel entre as fantasias inverossímeis demais para que alguém as confundisse com a realidade e os romances alusivos demais para que alguém suportasse suas referências ao real. A ideia de fiction abandona o falso, o engano, o fingimento, a mentira e a difamação para se limitar ao fictício. Ganha um estatuto novo e próprio quando os leitores começam a distingui-la "tanto da realidade como - sobretudo - da mentira" (GALLAGHER, 2009, p. 631).

$\mathrm{O}$ instrumento-chave para que o novel pudesse recusar a incômoda referencialidade, diz Gallagher, foi o nome próprio. "No século XVII e no começo do XVIII, as narrações críveis em prosa - inclusive aquelas que atualmente definimos como ficção - eram lidas como relatos reais" porque davam por certa a "correspondência entre um nome próprio e um indivíduo real" (GALLAGHER, 2009, p. 632). Em 1719, diz ela, Daniel Defoe quis enganar o público afirmando que existia um Robinson Crusoé e, sem dúvida, teve êxito. Mas...

em meados do século, um certo número de novels formulou um novo princípio teórico para uma nova forma literária: estas obras não falam de ninguém em particular, isto é, os nomes próprios não se referiam a indivíduos específicos reais, por conseguinte nenhum dos enunciados que contêm podem ser considerados verdadeiros ou falsos (GALLAGHER, 2009, p. 635). 
A novidade encontrou definição lapidar nas palavras de Henry Fielding em Joseph Andrews: "Eu não descrevo homens, mas costumes; não indivíduos, mas espécies". Já não se tratava apenas de evitar as acusações de fraudulência e difamação. $\mathrm{O}$ intuito era reivindicar "maior humanidade e maiores ambições para esta nova forma" (GALLAGHER, 2009, p. 636). Contra a literatura que lhe era imediatamente anterior, Fielding recorria à Poética de Aristóteles para postular que não se limitava a escrever sobre o que aconteceu, mas se permitia escrever sobre o que poderia acontecer. Os novos escritores recusaram que seus personagens fizessem referência a qualquer pessoa extratextual e, nisso, arrogaram-se o direito de fabular, de inventar seres e situações abstratas, derivadas do real, claro, mas sem ter com o mundo nenhum outro vínculo senão a plausibilidade das ocorrências.

Esse processo de transformação, continua Gallagher, foi natimorto na Espanha, hesitante na França, tardio nos Estados Unidos e preciso na Inglaterra, onde se encontraram as condições sociais e culturais para aquilo que Ian Watt denominou realismo formal: o materialismo, o capitalismo, o secularismo, o empirismo e o iluminismo científico, os quais proporcionaram a ascensão de uma burguesia que queria ver o próprio mundo descrito nas páginas, que preferira o crível à fantasia e o familiar ao exótico, que gostava de imaginar a existência simultânea de seus pares na nação (GALLAGHER, 2009, p.639). Os leitores burgueses agora sabiam que as personagens eram apenas seres típicos vivendo situações genéricas. Mas isso não os impedia de se identificar. Bem ao contrário. Sentiam que os anseios das personagens refletiam metonimicamente os seus próprios e os dos outros leitores, seus iguais.

Não foi pouco o que aconteceu na Inglaterra entre 1719 e 1742, diz Gallagher. Num momento, Defoe afirmava que Robinson Crusoé era uma pessoa real. No momento seguinte, Fielding não só autorizava o leitor a não acreditar na existência concreta das personagens como o desencorajava a fazê-lo - e, assim, o convidava a considerar a narrativa como uma especulação hipotética. Essa espécie de incredulidade se tornou o pressuposto da leitura ficcional e, em pouco tempo, advertências como as de Fielding não eram mais necessárias. O leitor de novel já não esperava realidade, mas sim plausibilidade, entendia que as personagens e os romances eram apenas metonimicamente, genericamente verdadeiros. O que aconteceu foi que o novel descobriu a ficção. Firmou com os leitores um pacto ficcional forte e inequívoco.

No último parágrafo do ensaio, porém, Catherine Gallagher aponta para mais uma mudança no conceito de fiction. Uma mudança que terá implicações sobre o entendimento contemporâneo da personagem - e também desse outro tipo de personagem: o narrador.
Tornou-se quase um lugar-comum dizer que o limite entre ficção e não ficção se está dissolvendo e que os nossos campos discursivos estão, mais uma vez, mudando de fisionomia. Historiadores e biógrafos cada vez mais apropriam-se das técnicas dos romancistas, apresentando livremente como fatos o que são conjecturas sobre as pessoas de quem falam, ou ainda introduzindo personagens e eventos fictícios. De sua parte, os romancistas pós-modernos adoram construir personagens ricas em referências a pessoas reais e desenterrar eventos históricos como se fossem de sua imaginação. Podemos prever que o jogo ontológico assumirá maior importância para os leitores do século XXI do que teve no curso dos tres séculos precedentes. Todavia, as novas formas narrativas mistas não tornarão obsoleta a pesquisa sobre o que sabemos acerca da fiç̧ão - ou seja, o que sua história legou para nossas práticas de leitura - ao contrário, irão tornala cada vez mais necessária (GALLAGHER, 2009, p. 657-658).

\section{O conceito de autoficção - a crise e o pacto ambíguo}

Penso que foi a esse pacto ficcional forte e inequívoco, a essa ideia de fiction que Antonio Candido se referiu quando falou na "marcha do romance moderno do século XVIII ao começo do XX". Tanto ele quanto Rosenfeld julgavam que a ficção se distinguia e se revelava em seus elementos intratextuais: a forma das orações, os verbos dicendi, a posição do narrador, os artifícios que criavam efeitos de onisciência e monólogo interior, tudo isso era indício de que o texto projetava seres e situações sem qualquer correspondência ao mundo extraliterário.

A diferença fundamental é que o historiador se situa, como enunciador real das orações, no ponto zero do sistema de coordenadas espaciotemporal, por exemplo, no ano de 1963 (e na cidade de São Paulo), projetando a partir deste ponto zero, através do pretérito plenamente real, o mundo do passado histórico igualmente real (ROSENFELD, 2002, p. 26).

Os enunciados de um sujeito real, escreveu Rosenfeld, ele próprio no ano de 1963 e na cidade de São Paulo, correspondiam à realidade dos objetos que enunciavam, e somente aí é que se podia falar de mentira, fraude ou erro. Já no âmbito da ficção - quando surgiu o conceito de ficção, Gallagher poderia assinalar - o enunciador real desaparecia. Verossimilhança era coerência interna. Nada a ver com a verdade.

Deviam mesmo ser muito nítidos os traços distintivos da ficção que Rosenfeld e Candido tomaram por objeto. Mas essa dessemelhança tão patente com a não ficção depois acabaria se perdendo nos "jogos ontológicos" que sobrevieram. De um lado, talvez ainda não se anunciasse 
à época de $A$ personagem de ficção a possibilidade de biógrafos e historiadores se valerem de recursos narrativos do romance - como viriam a admitir e explorar dali a pouco. ${ }^{1}$ De outro, talvez não fossem tão constantes as "novas formas narrativas mistas", as ditas ficções híbridas. Ou ainda: por estabelecer uma fronteira absoluta entre autor e narrador de textos ficcionais, pautada quem sabe por uma tal concepção segregacionista vinda da narratologia em voga, a crítica literária da época acabou por deixar que mesmo os hibridismos de então passassem por imperceptíveis - ou quase impensáveis (cf. COLONNA, 2014, p. 62). De todo modo, para Rosenfeld e Candido era seguro dizer que a ficção surgia da personagem e que o narrador ficcional não era "sujeito real de orações, como o historiador ou o químico" (ROSENFELD, 2002, p. 26).

Mas o que haveria de surgir quando a personagem já não fosse completamente fictícia? Que tipo de narrador ficcionista seria aquele que se colocasse no ponto zero do sistema de coordenadas espaciotemporal, que por inteiro nunca desaparecesse nem deixasse de se confundir com o autor? Que ficção seria a que não se revelasse nem se limitasse por sua coerência interna, que de alguma forma abraçasse a "solução difícil" do extratextual? E que ficção seria aquela que emulasse a não ficção, que incorporasse e fingisse mesmo a "evidência documentária" que deveria garantir alguma certeza "fora do próprio romance"?

Uma das tantas respostas a essas perguntas quem deu foi Serge Doubrovsky, quando, para definir sua autobiografia ficcional, ou sua ficção autobiográfica, cunhou o termo autoficção. Agora, o autor era e não era o narrador, contava e não contava sua vida, falava e não falava verdade, mentira, autobiografia e ficção.

Muito já se escreveu sobre autoficção. ${ }^{2}$ Os escritores e escritoras a tomam como possibilidade narrativa. As editoras, como aposta comercial. A academia, ora como gênero, ora como moda, ora como constante literária. Para muitos, o substantivo cunhado por Doubrovsky batiza

\footnotetext{
1 Aqui me refiro aos desdobramentos da virada linguística no âmbito da historiografia. Stone (1979) e Hobsbawm (1980) debateram o suposto retorno da narrativa aos textos historiográficos a partir dos anos 1960. Ladurie (original 1975), Ginzburg (original 1976) e Davis (1983) figuram, com maior ou menor justiça, entre os exemplos mais constantes desse retorno. White (original 1978) e o próprio Ginzburg (2007) passaram décadas discutindo o estatuto da verdade e das provas na história e na ficção. Mesmo que hoje soe findo e ultrapassado, tal debate parece ter perdido chances sucessivas de se endereçar à crescente complexidade ontológica e narrativa de textos ficcionais e também não ficcionais. Seria interessante, por exemplo, indagar a viabilidade de uma aproximação teórica entre os procedimentos híbridos os quais a autoficção compartilhou com outra onda editorial que se ergueu no fim dos anos 1970, a microhistória - estudo este que teria de questionar a posição do historiador no texto historiográfico contemporâneo (ADORNO, 2003).

2 Sobre as muitas indefinições que a fortuna crítica já acumula sobre o termo, ver Manuel Alberca (2007), Philippe Gasparini (2008), Régine Robin (2002), Graciela Speranza (2008) e, sobretudo, Ana Casas (2012) e Jovita Noronha (2014), as quais fazem belas compilações dos textos de Philippe Lejeune, Vicent Colonna, Jacques Lecarne, Serge Doubrovsky e Philippe Vilain, determinantes para o estudo do fenômeno.
}

essa nova atitude frente o pacto autobiográfico pouco antes definido por Lejeune - é uma recusa à verdade exata dos relatos sobre o real. Para muitos outros, a autoficção apenas atualiza uma série de vontades e artifícios que antes encontrou ecos em escritores como Calvino, Borges, Proust, Céline, Rousseau, Cervantes, Dante e daí desde sempre, até os romances gregos - é uma prova de que nunca foram exatas as relações e distinções entre os relatos sobre o real e o irreal. De um jeito e de outro, as tentativas de tipificação e mapeamento histórico das incontáveis amostras de tudo o que poderia se aproximar do termo acumulam definições e provocam uma inflação conceitual que acaba por englobar qualquer manifestação intermediária entre o romance e a autobiografia. Nas palavras de Gasparini, falta decidir "se a autoficção é $o$ nome atual de um gênero ou o nome de um gênero atual" (GASPARINI, 2014, p. 184). E talvez sempre falte muito mais que isso. O certo agora é que, ao procurar a homonímia entre autor, narrador e personagem, ou pelo menos ao confundir seus traços biográficos, os escritores que se aventuram nesses jogos híbridos e ambíguos estão tornando explícita e mesmo performática uma ruptura com a ilusão do pacto autobiográfico - mas talvez também estejam delineando uma das feições da morosa crise do pacto inequívoco proposto pelo novel.

Muito já se escreveu sobre a crise - as muitas crises, aliás - do romance. E talvez seja uma crise que se deixe entrever quando $A$ personagem de ficção sugere que "a marcha do romance moderno (do século XVIII ao começo do século XX)" seguiu no "rumo de uma complicação crescente" das personagens, de uma recusa contínua e paradoxal à "maior conquista" da ficção: sua capacidade de narrar pessoas mais nítidas e transparentes que as reais. A longa marcha do novel assim poderia ser lida como uma sucessão de crises e investidas contra a própria estrutura limitada, lógica e convencional da fiction, esse edifício que, em constante reforma, talvez tenha visto em Samuel Beckett a maior ameaça de uma desconstrução radical e quem sabe insuperável, ${ }^{3}$ um vórtice para o qual convergiram tantas outras crises - da arte, do sentido, da representação, da experiência, do sujeito (FUKS, 2016).

Ante a essas crises, ante a crise da própria ideia de inventar personagens e histórias fictícias, a autoficção apresenta uma resposta que, curiosamente e talvez não por acaso, retoma algo da ambivalência dos primórdios do romance, anterior à consolidação do conceito de fiction, também emprestando formas da autobiografia, do ensaio, do diário e da reportagem, revogando a fixidez do pacto

\footnotetext{
Enredo, personagem, cenário, voz narrativa, unidade de tempo e espaço, linguagem, todos os pilares do realismo formal que ascendera com o novel desmoronaram na prosa beckettiana do pós-guerra e além (cf. ANDRADE, 2001).
} 
autobiográfico e do ficcional para resgatar a instabilidade de um pacto híbrido, ambíguo, paradoxal. ${ }^{4}$

\section{A personagem de autoficção - o conhecimento dos outros e a escrita de si}

A partir da leitura de Anatol Rosenfeld e Antonio Candido, disse que o problema da origem da personagem é decisivo para o nexo entre criação e cópia, para a própria natureza dafiction. "Roland Barthes e os desmistificadores estruturalistas" não nos deixavam esquecer: le personnage n'est personne - personagem não é pessoa, não é ninguém em especial - e, como leitores, sabíamos que a personagem era uma convenção e que a "identificação consciente com ninguém [era] conatural à forma" do romance (GALLAGHER, 2009, p. 645, 648). Mas algo disso mudou quando o pacto ficcional deixou de ser forte, inequívoco, suficiente. Essa tal concepção segregacionista da narratologia deu lugar a uma concepção assimiladora, muito mais antiga, mais constante junto ao público e, paradoxalmente, mais afeita a consentir os fenômenos autoficcionais (COLONNA, 2014, p. 64).

No pacto da fiction, mesmo quando não expressa na capa do livro, a ficção se revelaria em caracteres exclusivamente intratextuais, e seria "por definição, e não por uma casual falta de documentação, que não [poderíamos] recorrer a fontes externas à ficção para obtermos informações suplementares sobre uma personagem" (GALLAGHER, 2009, p. 654). Mas é justamente isso o que hoje procuramos fora dos livros, nos links do Google, nos verbetes da Wikipédia, no real: a autoficção é a hipótese de uma realidade extraliterária. Ao recusar a absoluta diferença entre as biografias do autor e do narrador, o romance autoficcional como que vaza para os paratextos, pede para que sua leitura continue nas notas, nos prefácios, nas dedicatórias, nas quartas capas, nas entrevistas que o autor concede, nas noites de

\footnotetext{
4 Sobre o surgimento do romance a partir de um pacto ambivalente: "[Lennard Davis propõe] o romance como um discurso, isto é, como parte de uma rede discursiva que inclui cartas, leis, jornais e anúncios, todos eles envolvidos com a questão de estabelecer a distinção entre fato e ficção, ou, em seus termos, de investigar a matriz news/novel, que ele julga serem categorias centrais na definição das origens do gênero na Inglaterra setecentista. A confusão entre a natureza factual ou ficcional a que tinham acesso os leitores do final do século XVII e início do século XVIII se coloca, na sua visão, como um problema de ordem epistemológica a ser enfrentado pelos primeiros romancistas. Nos estágios iniciais, assim, o romance se apresentaria como uma ficção factual, porque, ao negar sua ficcionalidade, fingia um conteúdo de verdade que, em última instância, produzia um sentimento de ambivalência em seus leitores. Ao longo da primeira metade do século XVIII, testemunha-se um processo de diferenciação entre narrativas factuais (news), que iria gerar o jornalismo e a história, e as narrativas ficcionais (novel), de onde surgiria o romance. Segundo Davis, essa separação seria decisiva na constituição do novo gênero e foi dessa ruptura que surgiram os romances de Defoe, Richardson e Fielding, romancistas que exploraram, cada um à sua maneira, os limites novelísticos dessa relação entre fato e ficção, encontrando formas de escrever sobre o mundo que são simultaneamente inventivas e referenciais" (VASCONCELOS, 2007, p. 36).
}

autógrafo em que assina seu nome, nas informações e press releases que sua editora distribui, na recepção que a crítica lhe faz. E, assim, por tudo isso, a autoficção exige que se pense em noções de verdade e verossimilhança para além da coerência interna, que se abrace a solução difícil do extratextual.

Ainda que pareça frívolo ou vulgar, o impulso do leitor que aceita o jogo autoficcional e recorre aos paratextos acaba por comprometer a suficiência do estatuto da fiction. O que é verdade e o que é invenção? O que de fato aconteceu? Seu romance é autobiográfico? A pergunta da qual nenhum escritor consegue escapar é a que menos lhe interessa e, ao mesmo tempo, a que mais parece lhe garantir público e apelo. É também a que mais lhe permite performaticamente fingir origens, jogar jogos ontológicos e seguir escrevendo e caracterizando os personagens com o livro já publicado. De nada adiantaria teimar na injunção de que não se deve confundir autor com narrador com personagem, assim como de nada adiantaria se demorar na verificação minuciosa dos fatos narrados..$^{5} \mathrm{O}$ pacto é ambíguo. De um lado, o leitor sabe que aquela já não é a história de ninguém, que de algum modo o romance voltou a se referir à vida de alguém - que pode ser verdadeiro, falso, fraudulento, mitômano, litigável. Do outro lado, o escritor sabe se valer da salvaguarda da ficção. "O termo romance, lido no sentido forte, implica na verdade uma declaração de irresponsabilidade, ou um pacto de não referencialidade, que excluiria a visada autobiográfica" (LECARME, 2014, p. 88). Ao recusar pertença única ao romance ou à biografia, o autoficcionista reedita algo da instrução jurídica que safou os escritores que ajudaram a instituir o conceito de fiction nos primórdios do romance. Sempre que conveniente ou necessário, qualquer coincidência, semelhança ou homonímia deixa ostentar o "auto" para se abrigar no "ficcional". E assim a autoficção guarda o melhor de dois mundos: tanto a liberdade artística e a irresponsabilidade jurídica do romance quanto a referencialidade polêmica ou moralizante anterior à fiction. ${ }^{6}$

\footnotetext{
Numa palestra chamada, sintomaticamente, "Sobre ficção autobiográfica", Jonathan Franzen se põe a refletir sobre algumas "questões desagradáveis que costumam ser feitas a romancistas em eventos como este". Quais são suas influências? Quando você trabalha? Sua ficção é autobiográfica? Mesmo que passe um bom tempo pensando em sentidos mais profundos da ideia de biográfico, ele se diz "capaz de responder" à última das perguntas "com um sonoro e incondicional não". Ou, ironicamente, com um "Sim, 17\%. Próxima pergunta, por favor" (FRANZEN, 2012).

6 A passagem de Defoe a Fielding assinala também um deslocamento na ideia de exemplaridade. Enquanto o primeiro defendia o valor moral e edificante das histórias de vidas reais que trazia em suas obras, o segundo apostava na identificação do leitor com personagens típicos, genéricos, metonímicos, gente comum, que não era ninguém em especial, mas era um pouco todo mundo. A autoficção parece operar mais um deslocamento. Por um lado, continua uma tradição modernista de narrar à deriva, de contar a minúcia de momentos insignificantes em sua aparência (AUERBACH, 2004). Por outro, retoma algo do apelo das vidas dignas de serem contadas - seja pela virtude do testemunho de traumas, perdas, exílios e lutas, seja pelo escândalo da confissão de aventuras íntimas - o que, curiosamente, força alguns autores a desejar uma vida digna de autoficção.
} 
A partir da leitura de $A$ personagem de ficção, disse também que ficcional seria a coerência interna, o vigor dos detalhes, a verossimilhança de dados insignificantes, os artifícios que criam efeito de real, de personagens, de monólogos interiores, de uma onisciência que, por razões epistemológicas, não caberia a um enunciador real de orações, a um historiador que tentasse contar a vida dos outros, a um autobiografo que quisesse relembrar a própria. Mas a autoficção, ou pelo menos certa autoficção se recusa a ter ciência de tudo, pretende não reduzir as pessoas a personagens cristalinos e delimitados por uma série necessariamente finita de orações. $\mathrm{O}$ narrador se insinua autor de verdade e, ato contínuo, finge a ficção como mera tentativa de narrar a si e aos outros, obra que não se quer nem exaustiva nem determinante, que frente a seres inesgotáveis se sabe parcial, incompleta, inexata, momentânea talvez, como se fosse apenas uma versão possível de pessoas que existem no mundo - e que às vezes existem de fato e o acusam de fraude e difamação, o que curiosamente, performaticamente, acaba prolongando ao infinito, agora fora do texto, uma série de orações que serão incorporadas à leitura do livro.

É claro que, como qualquer outro personagem de romance, como qualquer outra pessoa biografada até, os nomes próprios que figuram nas autoficções são, para usar o termo de Candido, convencionalizados. Mas essa convencionalização parece querer negar o próprio ato: o narrador finge que não conseguiu realizá-la, pois, afinal, finge que é - e não é - um autor diante de pessoas de verdade, tentando narrar pessoas de verdade no livro que escreve. Ao se mostrar escrevendo o livro que o leitor terá em mãos, o narrador autoficcional inventa - e não inventa - pessoas que seriam reais e estariam antes e para além de seu esforço por reduzi-las a personagens ficcionais. É como se já não inventasse seres típicos vivendo situações genéricas, mas pessoas reais e sua tentativa de contá-las com palavras. Como se fosse vivendo e um dia the ocorresse relatar essa vida. E como se a escolha de gestos, de frases, de objetos significativos não fosse criada, estabelecida e racionalmente dirigida pelo escritor, mas fortuita, dada pelo real, alheia às conveniências do enredo, à necessidade de coesão e fechamento da trama. Daí a impressão de texto fraturado e heterogêneo, de que o escritor nos mostra o romance antes mesmo de pronto, a antessala de um livro inacabado porque, sempre indeciso, só avança na hesitação ao lembrar das coisas, na incerteza ao descrever os outros, nas dúvidas quanto ao que dizer e o que calar, na indefinição da forma. Impressão de texto inacabado e mesmo interminável porque seus enunciados continuam fora das páginas e bem poderiam se estender até o fim da vida do escritor. Poderiam, sobretudo, ser outros se fossem outras suas circunstâncias, seus encontros.
A ideia de encontro, também ela parece implicar uma insuficiência do conceito de fiction. No início do século XVIII, em diversas cartas, prefácios e artigos na imprensa, Daniel Defoe declarou seu desdém pela mera narração de peripécias extravagantes, seu desprezo pelas obras nas quais se inventavam personagens e situações que nunca existiram na natureza. Nisso insistiu que seus livros não eram romance, mas sim history, relatos pessoais, biografias. Para reforçar esse argumento, Defoe incluía no volume, quase sempre sob forma de prefácio, uma espécie de história da história, uma breve elucidação das circunstâncias nas quais o autor ou o editor descobrira a trajetória da pessoa cuja vida seria contada nas páginas seguintes. Tal descoberta envolvia no mais das vezes o encontro do autor/editor com essa pessoa ou pelo menos com seus manuscritos - e daí surgia um efeito ao mesmo tempo conveniente e poderoso: no paratexto, o autor/editor garantia que, uma vez com tais manuscritos em mãos, se esforçara para suprimir os vícios de sua linguagem baixa e cotidiana, as descontinuidades e inconsistências de seu relato. Assim se eximia de tudo o que pudesse haver de incoerente e descuidado no livro ao mesmo passo em que reforçava a sensação de espontaneidade e autenticidade da história (VASCONCELOS, 2007; FUKS, 2016). ${ }^{7}$ Dessa suposta materialidade do manuscrito, dessa fingida referencialidade a nomes próprios, dessa pretensa continuidade entre o mundo narrado e o mundo do autor/ editor, derivava toda a força da vindicação de real desses livros: vindicação histórica, biográfica, não ficcional anterior ao pacto da fiction, diria Gallagher.

Anos depois, esse procedimento dos manuscritos seria descartado por Fielding. Décadas depois, acabaria ironizado por Balzac (COLONNA, 2014, p.59). Já em Flaubert, tantas vezes visto como auge do romance, tudo o que num livro houvesse de incoerente e descuidado não produziria nenhum efeito de autenticidade nem veracidade. Ao contrário: sua posição diante dos personagens e acontecimentos era "totalmente diferente" daquela de Stendhal ou Balzac, ele não exprimia "qualquer opinião, não comentava", seu papel se restringia a "escolher os acontecimentos e a traduzi-los" em palavras límpidas e certeiras, sua arte repousava na "profunda confiança na verdade da linguagem empregada com responsabilidade, honestidade e esmero". O escritor flaubertiano não é editor de manuscritos, não tem materialidade. Está na obra como deus na natureza: invisível e mesmo ausente, não permite que se pronuncie seu nome (AUERBACH, 2004, p. 435, 436). Sinal de que a verossimilhança mudara e de que, no pacto inequívoco da fiction, o romance já não precisava ser simulacro de outros materiais e de outros

\footnotetext{
Curioso pensar que, com intenções e procedimentos parecidos, tal expediente passou a ser utilizado no início dos anos 1980 por um outro tipo de narrativa e sob outro nome: o found footage dos filmes de terror.
} 
gêneros, podia se assumir como linguagem própria, autônoma, suficiente, soberano para realizar a maior conquista da literatura: traçar os contornos definidos que sempre faltarão à nossa experiência.

Mas a paradoxal e insistente renúncia a essa maior conquista, o esforço contínuo contra as convenções limitadas e esquemáticas que conferiam um conhecimento cristalino das personagens, $\mathrm{o}$ anseio de repetir nas páginas o desconcerto que na vida sentimos diante das pessoas e do mundo - essas investidas todas arrastaram o romance por sucessivas crises de alta potência criadora, até que o levaram à ruína de seus pilares formais. Só restou à autoficção implodir os escombros do edifício da fiction. Ambíguo, o pacto autoficcional é tanto continuidade quanto ruptura com a longa marcha do romance, é um avanço para além da ficção e um retorno a seus primórdios, em busca de uma outra legitimidade. Os artifícios que vicejavam antes da consolidação da fiction voltam com mais força uma vez incorporadas - e já questionadas - as complexidades do romance modernista. Retorna a ambivalência entre pessoa e personagem, retorna a referencialidade em torno do nome próprio - agora do nome do escritor, que se torna uma espécie de autor/editor dentro das páginas. Na hesitação ao lembrar e escrever, vai juntando materiais heterogêneos, documentos com que tenta biografias de si e dos outros. E nisso vai contando a história e a história da descoberta e da escrita da própria história, suas circunstâncias e seus encontros com aqueles a quem narra. Escreve como que um prefácio contínuo, um paratexto que vaza para dentro do livro e a todo momento expõe e explora os impasses e os fracassos das próprias tentativas. Nessa estética de work in progress e making of, de abertura, deriva e indefinição, retorna algo do descuido, da errância e do encontro como efeito de veracidade: livro que conta duas histórias, a do narrado e a da narração, histórias que confundem duas biografias, a do narrador e do escritor, o romance autoficcional há muito deixou de ser fiction. É ficção híbrida. Pacto ambíguo.

Não falo aqui de todas as autoficções nem de nenhuma em especial. Tento muito mais imaginar suas potencialidades que recensear as manifestações tão diversas de um fenômeno contemporâneo que pode muito bem remontar a séculos. Entre meros escândalos e egotismos reinantes, haverá uns tantos romances, poucos, é verdade, a nos tocar com uma profunda impressão de fugidio, de livro interminável que continua no real, onde alguém escreve enquanto pensa nas impossibilidades da própria escrita. Se, depois de tantas crises formais, o gesto mais ingênuo de todos é confiar na capacidade de representação, o gesto mais interessante de todos seria desconfiar tanto da ficção quanto da autobiografia: desconfiar das convenções, criar outras convenções, logo recriá-las, desestabilizá-las - quem sabe o gesto autoficcional a expressar a potência renovada da literatura de hoje.

Em meio ao aglomerado crítico e teórico que se acumula, talvez só me reste uma hipótese: se toda a história do romance pudesse ser lida nas relações entre narrador e escritor, texto e paratexto, Beckett estaria de mãos dadas com Balzac, Defoe seria o mais contemporâneo de todos. Todo este artigo não é muito mais que a aposta na insuficiência do conceito de fiction. ${ }^{8} \mathrm{E}$ isso poderia sugerir que o pacto forte e inequívoco do romance foi uma exceção na literatura. E que a autoficção pode ser o nome atual de um gênero e também o nome de um gênero atual. Mas pode ser, sobretudo, uma atitude crítica da narrativa entre o real e o imaginário.

Marcel Proust passou anos não escrevendo sua Recherche. Melancólico numa sucessão de tentativas frustradas e desistidas, só pôde narrar a sequência infinda de tudo o que não lhe aconteceu até que de repente descobrisse a forma do romance que iria escrever: contou a vida qualquer, à espera da própria escrita. Contou a vida que viveu para enfim escrever o livro que temos em mãos.

Marcel Proust passou anos não escrevendo sua Recherche e não chegou a terminá-la. Porque a morte de seu corpo interrompeu sua autoria. E porque mesmo vivo jamais terminaria de se indagar sobre o desconhecimento que temos da vida dos outros, das pessoas mais amadas e das menos constantes, de Saint-Loup, de Albertine e de si mesmo, desse alguém que leva seu nome na página e que não pode senão contar seus impasses, seu fracasso, o tempo que perdeu até finalmente escrever seu romance, o tempo que faltou para terminá-lo, o tempo que sempre faltaria porque o desconcerto é mesmo interminável.

Hoje parece que no romance de Proust sobre o passado havia algo de futuro e também de crítico. Outra vez um outro pacto, um outro verossímil, outro verdadeiro. Outros personagens. Outro narrador. Esse que passa da ausência à presença. The one who loves changing from nothing to one.

\footnotetext{
8 A que se deveria a ascensão e queda desse conceito? Às sucessivas crises formais do romance? À falência de seu poder cultural enquanto mercadoria? Mas será que ruiu mesmo esse conceito? Ou a fiction pareceria insuficiente apenas para alguns círculos críticos e acadêmicos, seguindo forte como sempre nas prateleiras das livrarias? Nenhuma dessas perguntas tem resposta, por certo. Mas não deixa de ser interessante indagar se não estaríamos hoje reeditando algo da distinção pré-moderna assinalada por Gallagher: "Os primeiros novels procuravam distinguir-se das narrações plausíveis com referentes reais, não das histórias inverossímeis de inspiração fantástica (...) não salientavam o próprio realismo, mas sua natureza ficcional" (GALLAGHER, 2009, p. 640). Hoje parece que, ou as histórias são fantasiosas demais a ponto de ninguém as confundir com a realidade, ou são "baseadas em fatos reais", com forte referencialidade de nomes próprios.
} 


\section{Referências}

ADORNO, Theodor W. Notas de literatura I. Tradução e apresentação de Jorge M. B. de Almeida. São Paulo: Duas Cidades; Editora 34, 2003.

ALBERCA, Manuel. El pacto ambiguo: de la novela autobiográfica a la autoficción. Madrid: Biblioteca Nueva, 2007.

ANDRADE, Fábio de Souza. Samuel Beckett: o silêncio possível. São Paulo: Ateliê Editorial, 2001.

AUERBACH, Erich. Mimesis: a representação da realidade na literatura ocidental. Vários tradutores. São Paulo: Perspectiva, 2004 [original 1946].

CANDIDO, Antonio; ROSENFELD, Anatol; PRADO, Décio de Almeida; GOMES, Paulo Emílio. A personagem de ficção. São Paulo: Perspectiva, 2002 [original 1968].

CASAS, Ana (Org.). La autoficción: reflexiones teóricas. Madrid: Arco, 2012.

COLONNA, Vincent. Tipologia da autoficção. In: NORONHA, Jovita Maria Gerhein. Ensaios sobre a autoficção. Belo Horizonte: Editora UFMG, 2014.

DAVIS, Natalie Zemon. The return of Martin Guerre. Cambridge: Harvard, 1983.

DOUBROVSKY, Serge. Fils. Paris: Galilée, 1977.

FRANZEN, Jonathan. Como ficar sozinho. Tradução de Oscar Pilagallo. São Paulo: Companhia das Letras, 2012.

FUKS, Julián. História abstrata do romance. 2016. Tese (Doutorado) - Faculdade de Filosofia, Letras e Ciências Humanas, Universidade de São Paulo, 2016.

GALLAGHER, Catherine. Ficção. In: MORETTI, Franco (Org.). O Romance 1: a cultura do romance. Tradução de Denise Bottmann. São Paulo: Cosac Naify, 2009.

GASPARINI, Philippe. Autofiction: une aventure du language. Paris: Éditions du Seuil, 2008.

GASPARINI, Philippe. Autoficção é o nome de quê? In: NORONHA, Jovita Maria Gerhein. Ensaios sobre a autoficção. Belo Horizonte: Editora UFMG, 2014.

GINZBURG, Carlo. O queijo e os vermes: o cotidiano e as ideias de um moleiro perseguido pela Inquisição. Tradução de
Maria Betânia Amoroso. São Paulo: Companhia das Letras, 2001 [original 1976].

GINZBURG, Carlo. O fio e os rastros: verdadeiro, falso, fictício. Tradução de Rosa Freire d'Aguiar e Eduardo Brandão. São Paulo: Companhia das Letras, 2007.

HOBSBAWM, Eric. The revival of narrative: some comments [1980]. In: ROBERTS, Geoffrey. The History and Narrative Reader. Londres: Routledge, 2001.

LECARME, Jacques. Autoficção: um mau gênero? In: NORONHA, Jovita Maria Gerhein. Ensaios sobre a autoficção. Belo Horizonte: Editora UFMG, 2014.

LEJEUNE, Philippe. O pacto autobiográfico. Tradução de Jovita Maria Gerhein Noronha, Maria Inês Coimbra Guedes. Belo Horizonte: UFMG, 2008 [original 1975].

LE ROY LADURIE, Emmanuel. Montaillou, village occitan de 1294 à 1324. Paris: Gallimard, 1982 [original 1975].

PROUST, Marcel. Em busca do tempo perdido. Vol. 5: A prisioneira. Tradução de Manuel Bandeira e Lourdes Sousa de Alencar. São Paulo: Globo, 2006 [original 1923].

PROUST, Marcel. Em busca do tempo perdido. Vol. 7: O tempo redescoberto. Tradução de Lúcia Miguel Pereira. São Paulo: Globo, 2006 [original 1927].

ROBIN, Régine. La autoficción: el sujeto siempre en falta. In: ARFUCH, Leonor (Org.). Identidades, sujetos y subjetividades. Buenos Aires: Prometeo, 2002.

SPERANZA, Graciela. ¿Dónde está el autor? In: Otra parteRevista de Letras y Artes, n. 14, outono 2008.

STONE, Lawrence. The revival of narrative: reflections on a new old history [1979]. In: ROBERTS, Geoffrey. The History and Narrative Reader. Londres: Routledge, 2001.

VASCONCELOS, Sandra Guardini Teixeira. A formação do romance inglês: ensaios teóricos. São Paulo: Fapesp, 2007.

WHITE, Hayden. Trópicos do discurso: ensaios sobre a crítica da cultura. Tradução de Alípio Correia de Franca Neto. São Paulo: Edusp, 2001 [original 1978].

Recebido: $16 / 12 / 16$

Aprovado: 24/02/17

Contato: enatoprelorentzou@gmail.com 